Article

\title{
New Method of Determining Kinetic Parameters for Decomposition of Hydrogen Peroxide by Catalase
}

\author{
Ilona Trawczyńska \\ Department of Chemical and Bioprocess Engineering, Faculty of Chemical Technology and Engineering, \\ University of Science and Technology in Bydgoszcz, Seminaryjna 3, 85-326 Bydgoszcz, Poland; \\ ilona.trawczynska@utp.edu.pl
}

Received: 19 February 2020; Accepted: 9 March 2020; Published: 12 March 2020

\begin{abstract}
The presented study investigates the kinetic properties of catalase during hydrogen peroxide decomposition reaction. A novel and simple method is hereby proposed for the determination of the enzyme deactivation rate constant $\left(\mathrm{k}_{\mathrm{d}}\right)$ and the decomposition of $\mathrm{H}_{2} \mathrm{O}_{2}$ reaction rate constant $\left(\mathrm{k}_{\mathrm{r}}\right)$. Available methods allow the $\mathrm{k}_{\mathrm{d}}$ constant to be determined only based on previously experimentally determined $k_{r}$. The presented method differs from the conventional procedure. Known initial and final concentrations of hydrogen peroxide enable determination of both constants at the same time based on data from only one experiment. The correctness of the new method proposed here in determining the reaction rate constant was checked by comparing the obtained constant values with the calculated values according to the commonly used Aebi method. The method was used to analyze in detail the effect of $\mathrm{pH}(3-10)$ and temperature $\left(10-45^{\circ} \mathrm{C}\right)$ of the reaction medium on kinetic constants. The value of the constant $\mathrm{k}_{\mathrm{d}}$ increases together with the value of $\mathrm{pH}$ and temperature. In addition, the activation energy for decomposition reaction and deactivation reaction was found to be $E_{\mathrm{r}}=14 \mathrm{~kJ} \mathrm{~mol}^{-1}$ and $\mathrm{E}_{\mathrm{d}}=56.8 \mathrm{~kJ} \mathrm{~mol}^{-1}$ respectively.
\end{abstract}

Keywords: catalase; kinetic parameters; enzyme deactivation; enzyme activity

\section{Introduction}

Enzymes are highly efficient and selective biological catalysts under specific conditions, which makes their use extremely popular in various bioprocesses [1,2]. One of the common enzymes ubiquitously found in all living organisms is catalase [3,4]. Enzymes from various sources exhibit some differences in structure and properties [5-7]; nevertheless, all of them decompose hydrogen peroxide into molecular oxygen and water in the two-step process shown in Equation (1). In the first step, the heme-containing catalase bonds with and breaks up a molecule of hydrogen peroxide into harmless water and oxygen atom. This oxygen atom is joined to the iron atom present in the heme (Compound I). In the next step, a second hydrogen peroxide molecule binds and is also divided into two parts. After the second oxygen atom is attached to the iron atom the molecules of water and oxygen gas are released [8].

$$
\text { Catalase } \stackrel{+\mathrm{H}_{2} \mathrm{O}_{2} ;-\mathrm{H}_{2} \mathrm{O}}{\longrightarrow} \text { Compound I } \stackrel{+\mathrm{H}_{2} \mathrm{O}_{2} ;-\mathrm{H}_{2} \mathrm{O},-\mathrm{O}_{2}}{\longrightarrow} \text { Catalase }
$$

When $\mathrm{H}_{2} \mathrm{O}_{2}$ concentration is low, catalase can return to the native enzyme oxidizing secondary two-electron donors, e.g., low molecular alcohols (peroxidatic activity). A secondary two-electron donor participates in the second step of Equation (1) [9]. However, under certain conditions, Compound II can be created, but it cannot be effectively reduced to the native enzyme and therefore its accumulation leads to the catalase deactivation. Catalases may also form another intermediate product known as Compound III and are generally inactive towards most electron donors. Compound III structurally 
resembles oxy forms of mioglobin and hemoglobin. It can be generated in the reactions of Compound II with hydrogen peroxide, or ferric catalases with superoxide [9].

Catalase has a number of uses including food processing, the pharmaceutical and cosmetics industry, textiles, paper production, medical fields and also the bioremediation field [10,11]. Application of catalase in industrial processes is limited by the inability to withstand harsh operating conditions, e.g., high temperatures, extreme $\mathrm{pH}$ values, high detergent concentrations and high organic solvent concentrations [12]. The activity of the enzyme is lost due to changes in its spatial structure or polypeptide chain ruptures. Many operations have been applied in order to improve the use of enzymes in industry processes. The most popular of these is immobilization [13-16], which not only improves the catalytic stability of the enzyme but also allows its repeated use. There are also many reports on the improvement of enzyme activity using molecular biology methods $[17,18]$. Each technique is based on knowledge of the catalytic reaction mechanisms and the accompanying deactivation processes. Therefore, it is so important to look for new methods for determining the kinetic parameters of reactions that give us better understanding of the phenomena occurring during the reaction.

Decomposition of hydrogen peroxide using enzymes and deactivation of catalase follow first order kinetics with respect to the enzyme and substrate [19]. It has been shown that bovine liver catalase is both reversibly inhibited and irreversibly deactivated at high hydrogen peroxide concentration. Kinetic modeling has highlighted the role of Compound III in both types of activity loss [20]. Due to the phenomenon of substrate catalase deactivation, the use of this first order kinetics equation is only valid for low concentrations of hydrogen peroxide [21]. Information regarding the deactivation of catalase during the decomposition of hydrogen peroxide available in the literature refers mainly to deactivation using the substrate. There is no research concerning the effect of $\mathrm{pH}$ and temperature of the reaction mixture on bovine liver catalase deactivation rate.

Deactivation of catalase using substrate can be caused by the creation of inactive Compound II. Compound I from Equation (1) is an enzyme from an oxyferryl group with a $\pi$-cationic porphyrin radical. Forming of Compound II can result from the reduction of Compound I using a single electron (Equation (2) [22]).

$$
\text { Compound I }\left(\text { por }^{+\bullet}-\mathrm{Fe}^{\mathrm{IV}}=\mathrm{O}\right)+\mathrm{e}^{-} \rightarrow \text { Compound II }\left(\text { por }-\mathrm{Fe}^{\mathrm{IV}}=\mathrm{O}\right)
$$

The possibility of creating a hydroxyferryl form of Compound II was also demonstrated [23]:

$$
\text { Compound I }\left(\text { por }^{+\bullet}-\mathrm{Fe}^{\mathrm{IV}}=\mathrm{O}\right)+\mathrm{H}\left(\mathrm{H}^{+}+\mathrm{e}^{-}\right) \rightarrow \text { Compound II }\left(\text { por }-\mathrm{Fe}^{\mathrm{IV}}-\mathrm{OH}\right)
$$

Based on the above equations, the catalase deactivation is described using first order kinetics, and the dependence of the reaction rate, $\mathrm{v}_{\mathrm{d}}$, on $\mathrm{H}_{2} \mathrm{O}_{2}$ concentration assumes the following form:

$$
\mathrm{v}_{\mathrm{d}}=\mathrm{k}_{\mathrm{d}} \mathrm{C}_{\mathrm{S}} \mathrm{C}_{\mathrm{E}}
$$

where $C_{S}$ and $C_{E}$ represent the hydrogen peroxide concentration and active enzyme concentration respectively and $k_{d}$ is the enzyme deactivation rate constant.

This article provides a general mathematical procedure for the simulation of biochemical reactors operated batchwise when both the enzyme catalyzed reaction and the enzyme deactivation reaction take place. A novel method is proposed in order to calculate the kinetic parameters of enzyme reaction and deactivation. The effect of $\mathrm{pH}$ and temperature on the reaction rate constant of $\mathrm{H}_{2} \mathrm{O}_{2}$ decomposition and the rate constant of deactivation during the enzymatic process were analyzed in detail. Unlike the ordinary kinetic assays performed in a short time, the presented method requires determination of the final substrate concentration when the enzyme is completely deactivated. The method is based on experimental data from the decomposition of hydrogen peroxidase using bovine liver catalase. 
Catalase is one of the first enzymes obtained in crystalline form and a series of studies have been carried out on its activity, applications and methods of immobilization. However, the mechanism of action on $\mathrm{H}_{2} \mathrm{O}_{2}$ and the effects of environmental factors is still unclear. Catalase activity is significantly affected by the $\mathrm{pH}$ values of the aqueous medium and temperature [24]. So far, no one has studied the impact of these two factors on the kinetic parameters for hydrogen peroxide decomposition reaction using bovine liver catalase in wide range. Literature data is fragmentary and inconsistent [21,25-28]. Therefore, this study analyzed in detail the effect of $\mathrm{pH}$ and temperature on the reaction rate constant of $\mathrm{H}_{2} \mathrm{O}_{2}$ decomposition and the rate constant of deactivation during the enzymatic process.

\section{Results and Discussion}

A new element in the presented study is the method of determining $k_{d}$. In other works $[21,25,26]$, the algorithm of operation assumes determining first the value $\mathrm{k}$ based on the known initial concentration of the enzyme and on the initial linear slope of a first-order plot. Then, the value of $\mathrm{k}_{\mathrm{d}}$ was calculated. In this work there is no need to know the reaction rate constant of $\mathrm{H}_{2} \mathrm{O}_{2}$ decomposition, but one has to be sure that all the used enzyme is engaged and the final concentration of $\mathrm{H}_{2} \mathrm{O}_{2}$ is achieved.

\subsection{Effect of $\mathrm{pH}$}

To determine the kinetic parameters of the decomposition of $\mathrm{H}_{2} \mathrm{O}_{2}$, the reaction has to run with the excess substrate (Figure 1). The presented method also requires that the reaction has to last long enough to find a final concentration $\left(\mathrm{C}_{\mathrm{SF}}\right)$ of $\mathrm{H}_{2} \mathrm{O}_{2}$ after total deactivation of the enzyme (Table 1).

For known values of $C_{S 0}$ and $\Delta C_{S}$, based on Equation (14) the plots of $f\left(C_{S}\right)$ vs. time for each $p H$ were created (Figure 2). Afterwards, linear regressions were performed and the values of $k_{d}$ were determined from the slope of the solid line. The $\mathrm{R}^{2}$ coefficients were determined, and their values were higher than 0.98 for each case. These results demonstrate that the regressions are highly significant. The closer the $R^{2}$ is to 1 , the stronger the model is and the better it predicts the response.

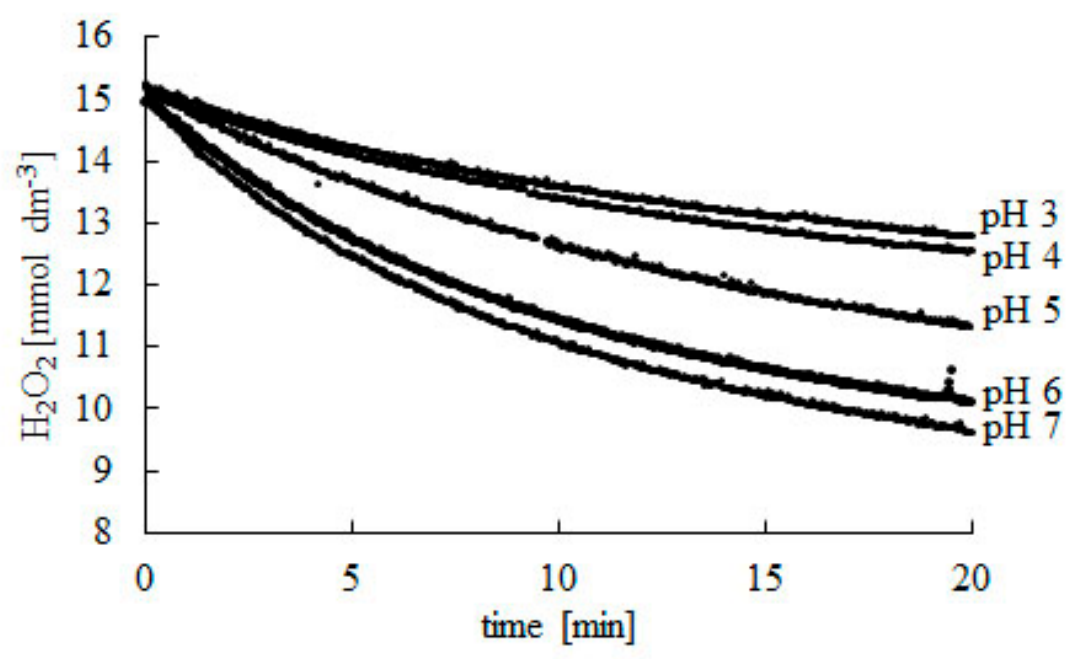

(a)

Figure 1. Cont. 


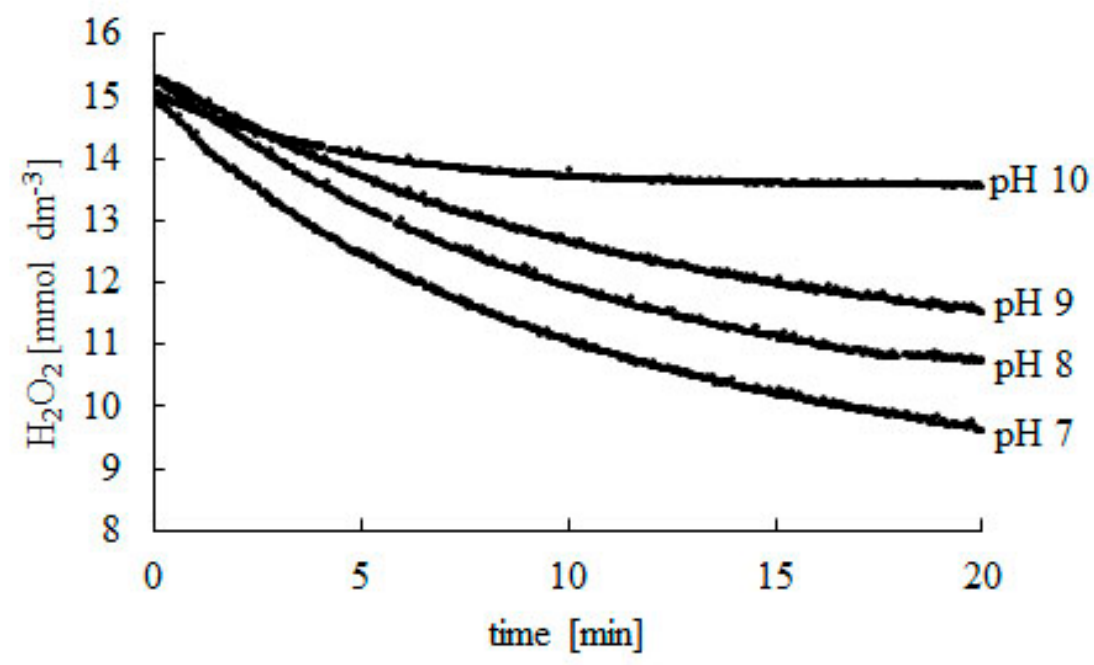

(b)

Figure 1. Change in $\mathrm{H}_{2} \mathrm{O}_{2}$ concentration during the decomposition reaction catalyzed using bovine liver catalase. (a) $\mathrm{pH} 3-7$, (b) $\mathrm{pH} 7-10$. Experiments were carried out at $25^{\circ} \mathrm{C}$. Readings were taken at 2-s intervals during $20 \mathrm{~min}$. Afterwards, readings were taken every $10 \mathrm{~min}$ until a constant $\mathrm{C}_{\mathrm{SF}}$ concentration was reached.

Table 1. Initial $\left(\mathrm{C}_{\mathrm{S} 0}\right)$ and final $\left(\mathrm{C}_{\mathrm{SF}}\right)$ concentration of hydrogen peroxide at different $\mathrm{pH}$.

\begin{tabular}{|c|c|c|c|}
\hline $\mathrm{pH}$ & $\begin{array}{c}\mathrm{C}_{\mathrm{S} 0} \\
\left(\mathrm{mmol} \mathrm{dm}^{-3}\right)\end{array}$ & $\begin{array}{c}\mathrm{C}_{\mathrm{SF}} \\
\left(\mathrm{mmol} \mathrm{dm}^{-3}\right)\end{array}$ & $\begin{array}{l}\text { Time } \\
\text { (min) }\end{array}$ \\
\hline 3 & 15.06 & 11.79 & 40 \\
\hline 4 & 15.02 & 11.61 & 50 \\
\hline 5 & 15.17 & 10.25 & 60 \\
\hline 6 & 15.08 & 9.39 & 70 \\
\hline 7 & 14.98 & 8.70 & 80 \\
\hline 8 & 15.10 & 9.04 & 40 \\
\hline 9 & 14.96 & 10.66 & 40 \\
\hline 10 & 15.05 & 13.48 & 12 \\
\hline
\end{tabular}

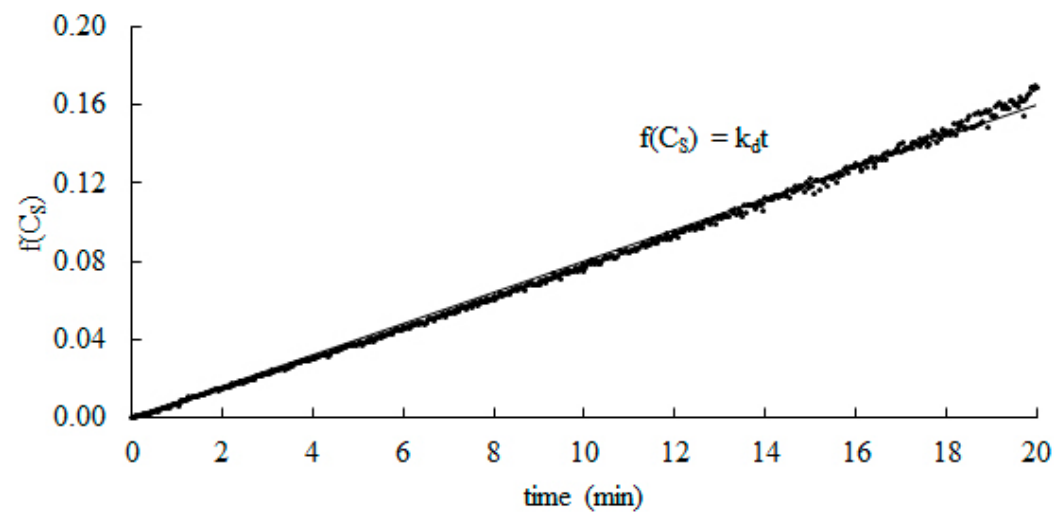

Figure 2. Typical plot of integrated rate equation for catalytic activity of catalase. Experiments were carried out at $25^{\circ} \mathrm{C}$ and $\mathrm{pH}=7$.

Figure 3 shows the effect of the $\mathrm{pH}$ of the reaction medium on the rate constant of the deactivation process. Changing the buffer used to ensure an adequate $\mathrm{pH}$ value may affect catalase activity [29]. To ensure the reliability of the results, experiments were performed using two different buffers on the 
border of their operation. Values of $k_{d}$ were very similar. In accordance to the line of the graph, the value of the constant $\mathrm{k}_{\mathrm{d}}$ increases together with $\mathrm{pH}$.

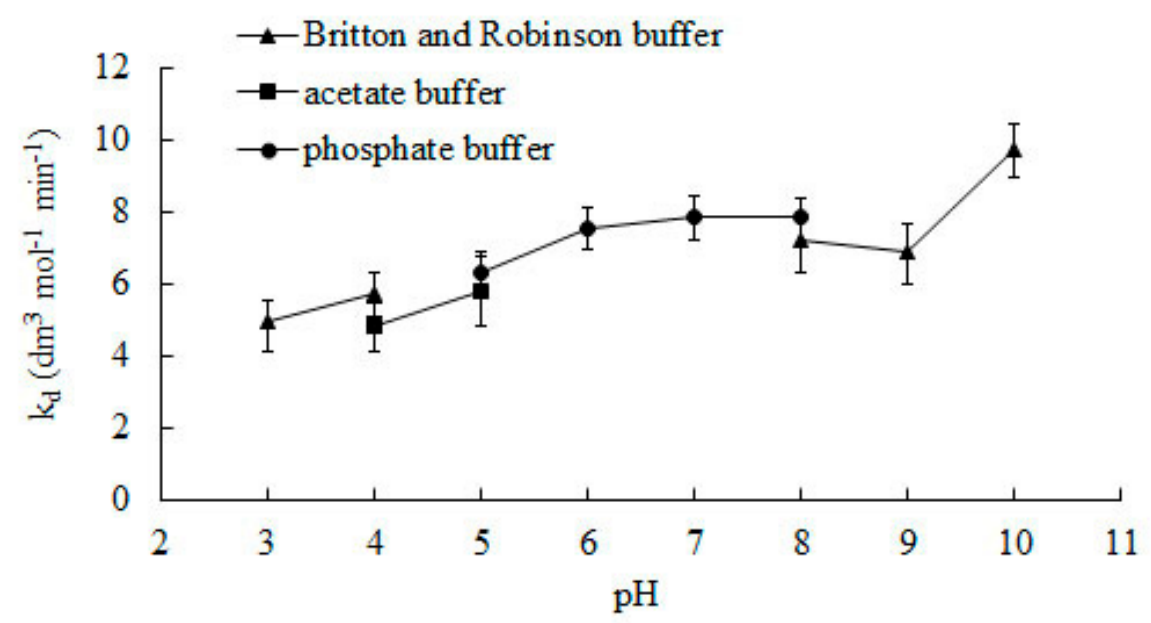

Figure 3. The effect of the $\mathrm{pH}$ of the reaction medium on the rate constant of deactivation during the enzymatic process. Error bars represent standard deviation mean of three replicates whilst means with the same letters in the same observation are not significantly different at 0.05 level of the LSD test.

So far, no one has presented research on the effect of $\mathrm{pH}$ on deactivating bovine liver catalase for the $\mathrm{H}_{2} \mathrm{O}_{2}$ decomposition reaction. In the literature, the deactivation constant can only be found for $\mathrm{pH}$ 7. The value of the constant $k_{d}$ determined by the presented method for this $\mathrm{pH}$ is $7.85 \mathrm{dm}^{3} \mathrm{~mol}^{-1}$ $\mathrm{min}^{-1}$ and is ca. $13 \%$ and $6 \%$ lower than those determined by Deluca et al. [26] and Feuers et al. [25].

For known values of the enzyme deactivation rate constant $\left(k_{d}\right)$ and $\Delta C_{S}$, based on Equation (12) the reaction rate constants $\mathrm{k}$ were determined. The reaction rate constant was also calculated using the Aebi method [30], based on the results of the decrease in the substrate concentration during the first minute of the experiment. The calculation results for both methods are presented in Figure 4.

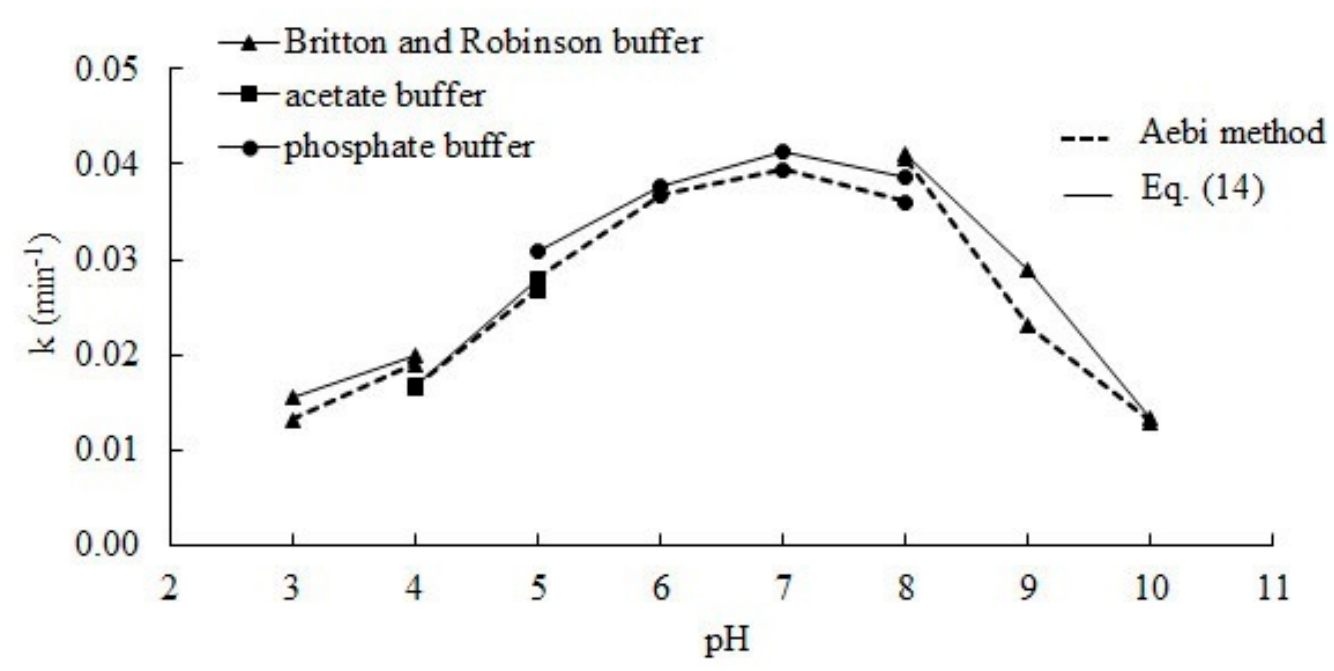

Figure 4. The effect of the $\mathrm{pH}$ of the reaction medium on the hydrogen peroxide decomposition rate constant.

Figure 4 shows changes in the hydrogen peroxide decomposition rate constant value, which depends on the $\mathrm{pH}$ ranging from 3 to 10 . The results obtained for the constant $\mathrm{k}$ using the presented method, based on Equation (12), are in all cases slightly higher and do not differ much from those calculated according to the Aebi method [30]; this result proves the correctness of the presented method. 
The Aebi method assumes that deactivation can be omitted because the measurement time is very short. In fact, with about a one-minute measurement time, slight deactivation should occur, and a lower reaction rate constant (97\% to 99\%) can be explained in this way. From the plot we can observe a high $\mathrm{k}$ value within the range of $6-8$, while below and above this range, a significant decrease of rate constant is noticed. The curve shape from Figure 4 will be identical for the relation $\mathrm{k}_{\mathrm{r}}$ to $\mathrm{pH}$, therefore it can be compared with the results presenting activity. Similar results were obtained by Kaushal et al. [11]. Activity of catalase decreased by $50 \%$ at $\mathrm{pH} 9$, but in the acid region it decreased by ca. $80 \%$. The acid segment of the curve also differs from what was obtained by Chance [27]; this result can be caused by usage of different buffer in this range of $\mathrm{pH}$. Most studies on catalase activity at various $\mathrm{pH}$ were conducted in a narrow $\mathrm{pH}$ range. The curve (Figure 4) is also consistent with the Góth's [28] results, however a comparison is only possible in the range of 6-8.

\subsection{Effect of Temperature}

Among the parameters affecting enzyme activity, temperature is the most important because it can be easily manipulated, and it affects not only the catalytic reaction rate but also the rate of deactivation of the enzyme [24]. The effect of temperature on the kinetic parameters of decomposition of $\mathrm{H}_{2} \mathrm{O}_{2}$ was studied in this work by carrying out the reaction at different temperatures of reaction medium, in the range of $10-45{ }^{\circ} \mathrm{C}$. The rate constant of deactivation during the enzymatic process and reaction rate constant of $\mathrm{H}_{2} \mathrm{O}_{2}$ decomposition were determined in the same way as for $\mathrm{pH}$ effect analysis. The rate constants $k_{d}$ were calculated as the slope of the line from Figure 2. The results, with their standard deviations SD and determination coefficients $\mathrm{R}^{2}$, are presented in Table 2.

Table 2. Effect of the temperature of the reaction medium on the rate constant of deactivation during the enzymatic process, $\mathrm{pH}=7$. Data for which $\mathrm{R}^{2}$ values are not reported are from the literature cited.

\begin{tabular}{|c|c|c|}
\hline $\begin{array}{c}\text { Temperature } \\
\left({ }^{\circ} \mathrm{C}\right)\end{array}$ & $\begin{array}{c}k_{\mathrm{d}} \pm \mathrm{SD} \\
\left(\mathrm{dm}^{3} \mathrm{~mol}^{-1} \min ^{-1}\right)\end{array}$ & $\mathbf{R}^{2}$ \\
\hline 10 & $1.83 \pm 0.15$ & 0.989 \\
\hline 15 & $2.32 \pm 0.21$ & 0.994 \\
\hline 25 & $7.85 \pm 0.22$ & 0.998 \\
\hline 35 & $13.04 \pm 0.54$ & 0.991 \\
\hline 40 & $16.42 \pm 1.90$ & 0.990 \\
\hline 45 & $24.81 \pm 3.30$ & 0.989 \\
\hline 25 & 8.9 & Deluca et al. [26] \\
\hline 25 & 8.34 & Feuers et al. [25] \\
\hline 27 & 6.86 & $\begin{array}{l}\text { Ghadermarzi and } \\
\text { Moosavi-Movahedi [21] }\end{array}$ \\
\hline
\end{tabular}

From the data shown in Table 2, it was observed that the constant $k_{d}$ increases together with temperature. It was detected that $\mathrm{k}_{\mathrm{d}}$ increased ca. 14 times whilst temperature increased from $10^{\circ} \mathrm{C}$ to $45^{\circ} \mathrm{C}$. It is clear that in the conditions adopted in these tests, $45^{\circ} \mathrm{C}$ is not a convenient temperature for the process and a lower value should be adopted.

The rate constant of deactivation $k_{d}$ values for catalase from bovine liver are much higher than those obtained by Miłek [31] for fungal catalase. Comparing the results (Figure 5) confirms that catalase from animal tissues more easily tends to convert into a catalytically inactive form than those obtained from microorganisms.

Rate constants of catalase deactivation were presented as an Arrhenius plot (Figure 6), and the activation energy for catalase deactivation was estimated $\left(E_{\mathrm{d}}=56.8 \mathrm{~kJ} \mathrm{~mol}^{-1}\right)$.

Values of the determination coefficient $\left(R^{2}=0.9813\right)$ points out goodness of regression, which can be used to explain $98.13 \%$ of total variation in the response. The activation energy of catalase deactivation is three times lower than the activation energy for catalase deactivation in water in the presence of substrate estimated by Cantemir et al. [29]. 


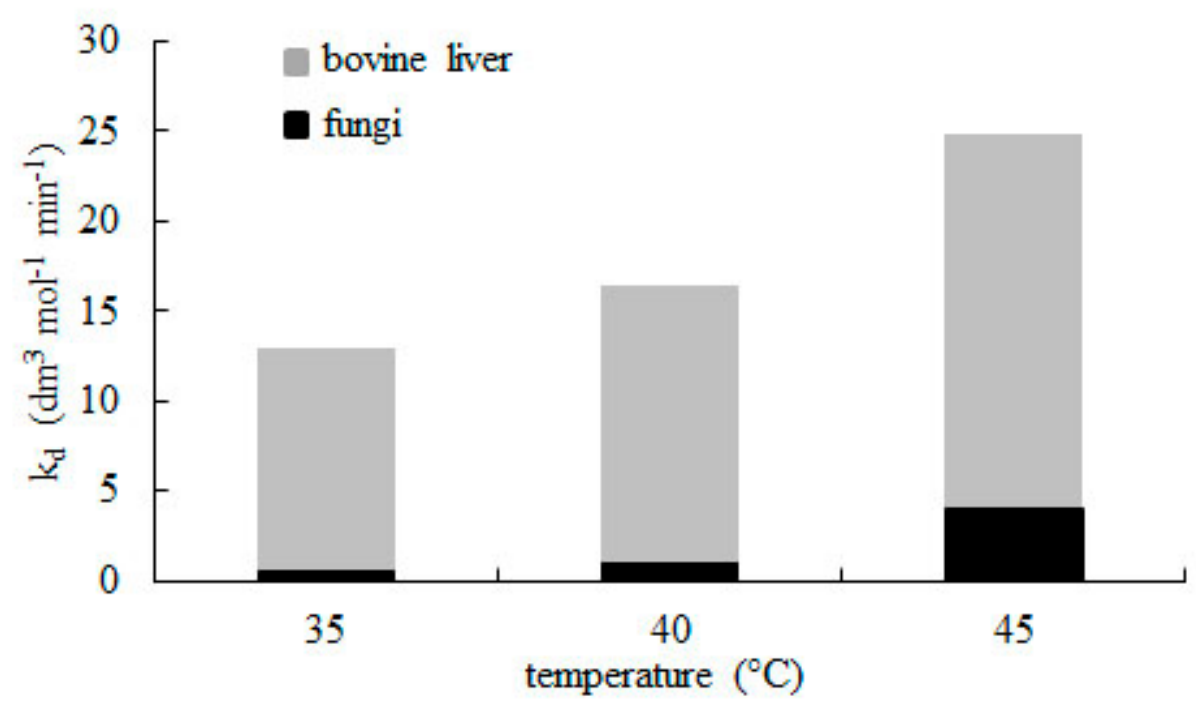

Figure 5. Comparision between rate constant of catalase deactivation $\left(k_{d}\right)$ for enzyme from bovine liver and fungi [31]. Decomposition was conducted using $15 \mathrm{mmol} \mathrm{dm}^{-3}$ hydrogen peroxide at $\mathrm{pH}=7$.

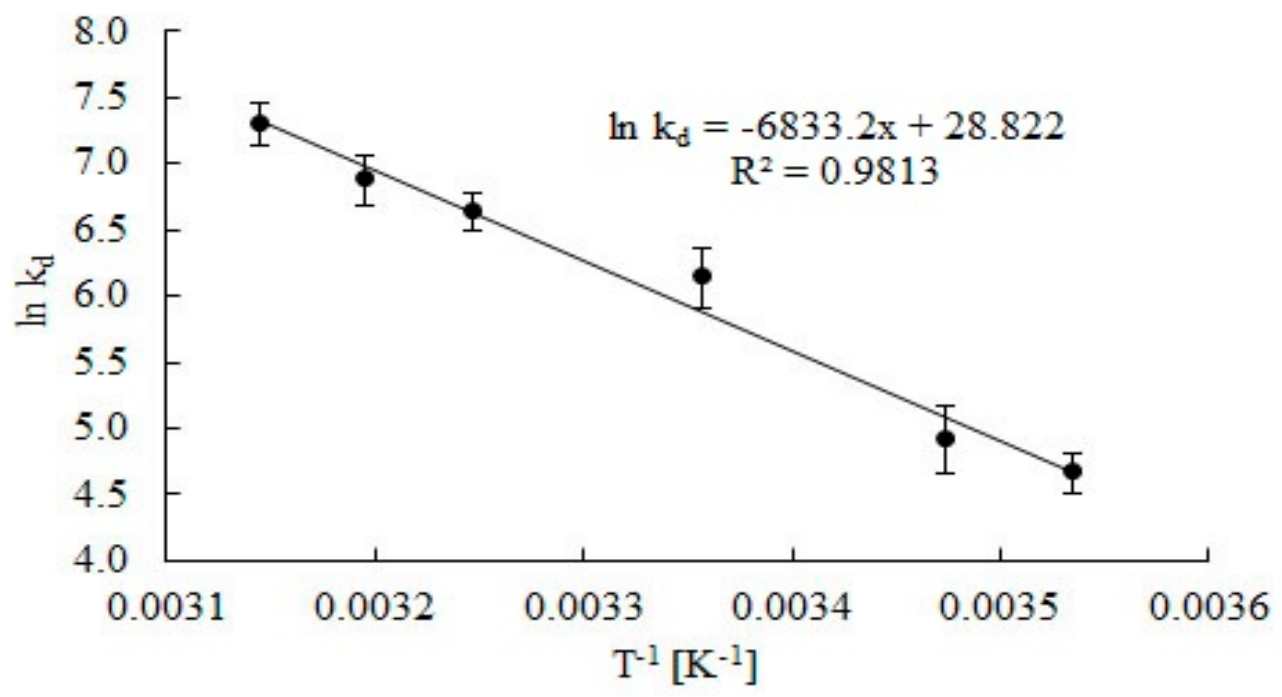

Figure 6. Arrhenius plots to calculate activation energy $E_{d}$ catalase deactivation during the decomposition of $\mathrm{H}_{2} \mathrm{O}_{2}$. Error bars represents the standard deviation mean of three replicates, while means with the same letters in the same observation are not significantly different at 0.05 level of the LSD test.

Based on known values of $k_{d}, \Delta C_{S}$ and Equation (12) reaction rate constants $k$ were determined. The obtained results were compared with those calculated according to the Aebi method [30]. The results obtained with both methods do not differ significantly from each other. Effect of the temperature of the reaction medium on the hydrogen peroxide decomposition rate constant is presented in Figure 7 for temperatures of $10-45^{\circ} \mathrm{C}$. Together with temperature increase, a large increase of the reaction rate constant value is observed, but after exceeding $25^{\circ} \mathrm{C}$, constant $\mathrm{k}$ does not change significantly.

Figure 8, the Arrhenius activation energy for decomposition of $\mathrm{H}_{2} \mathrm{O}_{2}$ was determined. Value of $\mathrm{E}_{\mathrm{r}}$ was calculated to be $14 \mathrm{~kJ} \mathrm{~mol}^{-1}$ and is slightly higher than estimated by Góth [28]. For an enzyme from the same supplier (Sigma), the activation energy is reduced by $5.8 \mathrm{~kJ} \mathrm{~mol}^{-1}$. However, catalase activity was measured using a different method. Moreover, activation energy was calculated according to the Arrhenius plot, based on determination of enzyme activities at four temperatures in a narrow range between 20 and $33^{\circ} \mathrm{C}$. The value of calculated activation energy for decomposition of $\mathrm{H}_{2} \mathrm{O}_{2}$ is four times lower than the catalase deactivation energy. The energy necessary to start the deactivation 
reaction is much higher than the energy needed to initiate the catalytic reaction. This result confirms other authors' findings [31-33].

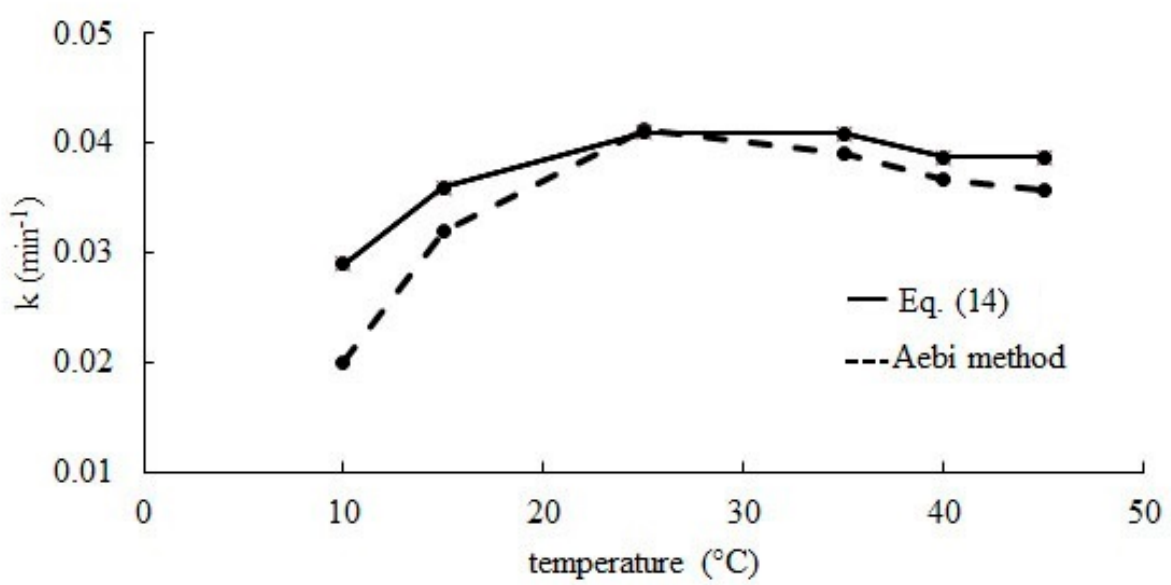

Figure 7. The effect of temperature on the hydrogen peroxide decomposition rate constant.

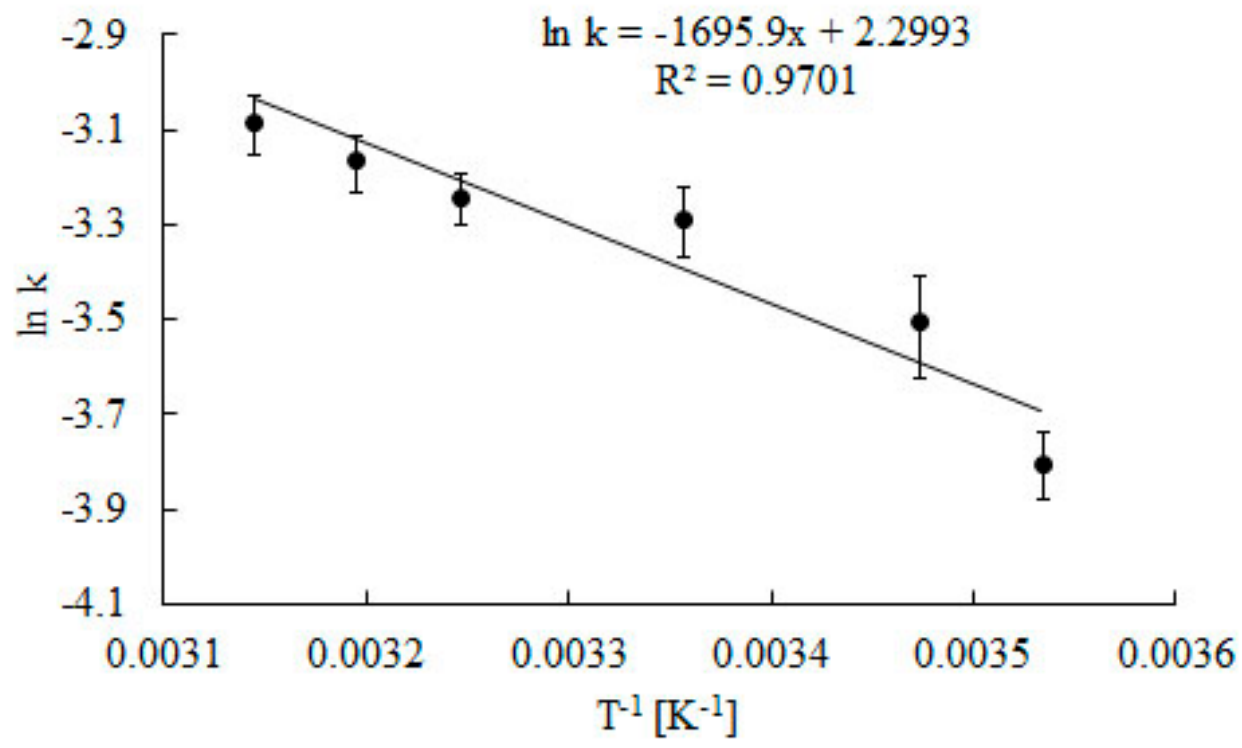

Figure 8. Arrhenius plots to calculate activation energy for $\mathrm{E}_{\mathrm{r}}$ decomposition of $\mathrm{H}_{2} \mathrm{O}_{2}$ reaction. Error bars represent the standard deviation mean of three replicates, while means with the same letters in the same observation are not significantly different at 0.05 level of the LSD test.

\section{Materials and Methods}

\subsection{Materials}

For all experiments, bovine liver catalase (EC 1.11.1.6) was purchased from Sigma Aldrich (Poznań, Poland). Hydrogen peroxide $\left(\mathrm{H}_{2} \mathrm{O}_{2}, 30 \%\right)$, monosodium phosphate $\left(\mathrm{NaH}_{2} \mathrm{PO}_{4}\right)$, sodium phosphate dibasic heptahydrate $\left(\mathrm{Na}_{2} \mathrm{HPO}_{4} \cdot 7 \mathrm{H}_{2} \mathrm{O}\right)$, acetic acid $\left(\mathrm{CH}_{3} \mathrm{COOH}, 99 \%\right)$, sodium acetate $\left(\mathrm{CH}_{3} \mathrm{COONa}\right)$, phosphoric acid $\left(\mathrm{H}_{3} \mathrm{PO}_{4}, 85 \%\right)$, boric acid $\left(\mathrm{H}_{3} \mathrm{BO}_{3}, 99 \%\right)$ were purchased from Avantor Performance Materials Poland S.A. (Gliwice, Poland).

\subsection{Decomposition of Hydrogen Peroxide}

Decomposition of hydrogen peroxide was measured using the method of Beers and Sizer [34]. Spectrophotometer Helios was used to measure the decrease in the absorbance (at $240 \mathrm{~nm}$ ) during the decomposition of $\mathrm{H}_{2} \mathrm{O}_{2}$. The system allows for continuous reading of absorbance. Reaction was 
carried out within the isothermal batch reactor with mixing. Decomposition of hydrogen peroxide was started by adding a buffered catalase solution $\left(\mathrm{pH} 7,17.5 \mathrm{U} \mathrm{mL}^{-1}\right)$. Initial concentration of $\mathrm{H}_{2} \mathrm{O}_{2}$ in the reaction mixture was chosen to be $15 \mathrm{mmol} \mathrm{dm}^{-3}$. The substrate concentrations were calculated using the Lambert-Beer law, with extinction coefficient $39.4 \mathrm{M}^{-1} \mathrm{~cm}^{-1}$. A number of preliminary tests were performed to ensure that observed effects were caused by enzyme deactivation and not due to exhaustion of substrate, inhibition by reaction byproducts or slow heating of samples.

\subsection{Determination of Kinetic Parameters}

Consideration of an isothermal reactor with perfect mixing gives a system of two ordinary differential equations

$$
\begin{array}{r}
-\frac{d C_{S}}{d t}=k_{r} C_{E} C_{S} \\
-\frac{d C_{E}}{d t}=k_{d} C_{E} C_{S}
\end{array}
$$

where $C_{S}$ and $C_{E}$ represent the hydrogen peroxide concentration and active enzyme concentration respectively. The initial conditions are $C_{S}(t=0)=C_{S 0}$ and $C_{E}(t=0)=C_{E 0}$. First one kinetic model (Equation (5)) describes decomposition of hydrogen peroxide reaction with $\mathrm{k}_{\mathrm{r}}$ as a rate constant. The second model (Equation (6)) defines deactivation of catalase with $\mathrm{k}_{\mathrm{d}}$ as a rate constant. Measurement of active enzyme concentration during the experiment is not possible. It is convenient to introduce the fraction of catalase activity

$$
\mathrm{A}=\frac{\mathrm{C}_{\mathrm{E}}}{\mathrm{C}_{\mathrm{E} 0}}
$$

where $\mathrm{k}=\mathrm{k}_{\mathrm{r}} \mathrm{C}_{\mathrm{E} 0}$, and the initial conditions are $\mathrm{C}_{\mathrm{S}}(\mathrm{t}=0)=\mathrm{C}_{\mathrm{S} 0}$ and $\mathrm{A}(\mathrm{t}=0)=1$ for Equations (5) and (6) are as follows:

$$
\begin{aligned}
& -\frac{\mathrm{dC}_{\mathrm{S}}}{\mathrm{dt}}=\mathrm{kAC}_{\mathrm{S}} \\
& -\frac{\mathrm{dA}}{\mathrm{dt}}=\mathrm{k}_{\mathrm{d}} \mathrm{AC}_{\mathrm{S}}
\end{aligned}
$$

Integration of differential Equations (5) and (6) for $k \neq k_{d} C_{S 0}$ gives

$$
\mathrm{A}=1-\frac{\mathrm{k}_{\mathrm{d}}}{\mathrm{k}}\left(\mathrm{C}_{S_{0}}-\mathrm{C}_{S}\right)
$$

In a certain case where $\mathrm{k}=\mathrm{k}_{\mathrm{d}} \mathrm{C}_{\mathrm{S} 0}$ hydrogen peroxide concentration is given by

$$
\mathrm{C}_{\mathrm{S}}=\frac{\mathrm{C}_{\mathrm{S} 0}}{\mathrm{kt}+1}
$$

The determination of the $\mathrm{k}$ and $\mathrm{k}_{\mathrm{d}}$ constants can easily be carried out when the amount of used catalase is not sufficient to decompose the total amount of $\mathrm{H}_{2} \mathrm{O}_{2}$ because the enzyme will be completely deactivated. In such a case, the difference in substrate concentrations for the final activity of catalase A $=0$ is described based on Equation (10) in the following way:

$$
\mathrm{C}_{\mathrm{S} 0}-\mathrm{C}_{\mathrm{SF}}=\Delta \mathrm{C}_{\mathrm{S}}=\frac{\mathrm{k}}{\mathrm{k}_{\mathrm{d}}}
$$

Based on Equations (10) and (12) and after rearranging (supplement material) we obtain

$$
\frac{\ln \left(\frac{C_{S} \Delta C_{S}}{C_{S 0}\left(C_{S}+\Delta C_{S}-C_{S 0}\right)}\right)}{C_{S 0}-\Delta C_{S}}=k_{d} t
$$

From Equation (13), the enzyme deactivation rate constant $k_{d}$ can be taken from linear regression on Equation (14). 


$$
f\left(C_{S}\right)=\frac{\ln \left(\frac{C_{S} \Delta C_{S}}{C_{S 0}\left(C_{S}+\Delta C_{S}-C_{S 0}\right)}\right)}{C_{S 0}-\Delta C_{S}}=k_{d} t
$$

where the slope is equal to the enzyme deactivation rate constant. Using the known values of $k_{d}$ and $\Delta \mathrm{C}_{\mathrm{S}}$, reaction rate constant $\mathrm{k}$ can be calculated.

\subsection{Effect of $\mathrm{pH}$ and Temperature}

The effect of $\mathrm{pH}$ on the kinetic parameters was analyzed by carrying out the decomposition reaction of buffered hydrogen peroxide solution $15 \mathrm{mmol} \mathrm{dm}^{-3}$ at $25{ }^{\circ} \mathrm{C}$ over the $\mathrm{pH}$ range $3-10$ using the following buffers: $0.05 \mathrm{M}$ Britton and Robinson ( $\mathrm{pH} 3-4, \mathrm{pH} 8-10), 0.05 \mathrm{M}$ acetate ( $\mathrm{pH} 4-6)$ and $0.05 \mathrm{M}$ phosphate ( $\mathrm{pH}$ 6-8).

Further insight into details of the decomposition of hydrogen peroxide and deactivation of catalase was gained from the temperature dependence of rate constants. The effect of temperature was tested performing decomposition reactions in various temperatures ranging from 10 to $45^{\circ} \mathrm{C}$. The experimental data analysis was based on the Arrhenius relationship

$$
\mathrm{k}_{\mathrm{d}}=\mathrm{k}_{\mathrm{d} 0} \exp \left(\frac{-\mathrm{E}_{\mathrm{D}}}{\mathrm{RT}}\right)
$$

where $k_{\mathrm{d} 0}$ is specific constant for the deactivation, $E_{D}$ is an activation energy for enzyme deactivation, $\mathrm{R}$ is the universal gas constant and $\mathrm{T}$ is the absolute temperature. The $\mathrm{E}_{\mathrm{D}}$ was evaluated from the linear regression $\ln \left(\mathrm{k}_{\mathrm{d}}\right)$ vs. $\mathrm{T}^{-1}$. Catalase activation energy $\mathrm{E}_{\mathrm{r}}$ for $\mathrm{H}_{2} \mathrm{O}_{2}$ decomposition was also determined using the Arrhenius equation

$$
\mathrm{k}=\mathrm{k}_{0} \exp \left(\frac{-\mathrm{E}_{\mathrm{r}}}{\mathrm{RT}}\right)
$$

where $\mathrm{k}_{0}$ is specific constant for the reaction of $\mathrm{H}_{2} \mathrm{O}_{2}$ decomposition. After plotting $\ln (\mathrm{k}) \mathrm{vs}$. $\mathrm{T}^{-1}$, the activation energy was estimated from the slope of the linear portion of the plot.

\subsection{Statistical Analysis}

Calculations for rate constants and activation energy were performed using Microsoft Excel 2016 and StatSoft Statistica (Krakow, Poland). The value of rate constants for deactivation of catalase were determined using linear regression using the least squares method (Levenberg-Marquardt). Basic descriptive statistics have been used, such as mean standard deviations and determination coefficient $\mathrm{R}^{2}$. Fisher's least significant difference (LSD) was carried out at a $95 \%$ confidence interval to check the significance difference among the means- the mean square due to regression and the mean square due to error.

\section{Conclusions}

This study presents a new method to establish the kinetic parameters for hydrogen peroxide decomposition reaction using catalase from bovine liver. It has been shown that it is possible to determine the $\mathrm{k}_{\mathrm{d}}$ constant only using data of $\mathrm{H}_{2} \mathrm{O}_{2}$ concentration changes. In addition, this method allows the determination of both $\mathrm{k}_{\mathrm{d}}$ and $\mathrm{k}_{\mathrm{r}}$ constants at the same time based on one experiment. The results of the constant reaction rate of $\mathrm{H}_{2} \mathrm{O}_{2}$ decomposition obtained using the presented method are very close to the results calculated using the popular Aebi method [30]. Research confirms the range of $\mathrm{pH}$ to achieve the high values of the rate constant, i.e., 6-8. Studies have also shown the degree of deactivation of the enzyme which occurs in parallel with the reaction of hydrogen peroxide decomposition. The method might be applicable to enzymes in general and can be used to determine if the enzyme exposed to external factors undergoes mechanisms of deactivation.

Supplementary Materials: The following are available online at http://www.mdpi.com/2073-4344/10/3/323/s1. 
Funding: This research received no external funding.

Acknowledgments: The author is thankful to Marek Wójcik for providing valuable comments and feedback at various stages of this research.

Conflicts of Interest: The authors declare no conflict of interest.

\section{References}

1. Zhang, Y.; Shudong, H.; Simpson, B.K. Enzymes in food bioprocessing-Novel food enzymes, applications, and related techniques. Curr. Opin. Food Sci. 2018, 19, 30-35. [CrossRef]

2. Madhu, A.; Chakraborty, J.N. Developments in application of enzymes for textile processing. J. Clean Prod. 2017, 145, 114-133. [CrossRef]

3. Zamocky, M.; Koller, F. Understanding the structure and function of catalases: Clues from molecular evolution and in vitro mutagenesis. Prog. Biophys. Mol. Biol. 1999, 72, 19-66. [CrossRef]

4. Peter, C.L.; Martin, G.K.; Daniel, J.H. Catalase-an "old" enzyme that continues to surprise us. ASM News 2000, 66, 76-78.

5. Melik-Adamyan, W.R.; Barynin, V.V.; Vagin, A.A.; Borisov, V.V.; Vainshtein, B.K.; Fita, I.; Murthy, M.R.; Rossmann, M.G. Comparison of beef liver and Penicillium vitale catalases. J. Mol. Biol. 1986, 188, 63-72. [CrossRef]

6. Sharma, K.D.; Andersson, L.A.; Loehr, T.M.; Terner, J.; Goff, H.M. Comparative spectral analysis of mammalian, fungal, and bacterial catalases. Resonance Raman evidence for iron-tyrosinate coordination. J. Biol. Chem. 1989, 264, 12772-12779.

7. Chelikani, P.; Fita, I.; Loewena, P.C. Diversity of structures and properties among catalases. Cell. Mol. Life Sci. 2004, 61, 192-208. [CrossRef]

8. Fita, I.; Rossmann, M.G. The active center of catalase. J. Mol. Biol. 1985, 185, 21-37. [CrossRef]

9. Gebicka, L.; Krych-Madej, J. The role of catalases in the prevention/promotion of oxidative stress. J. Inorg. Biochem. 2019, 197, 110699. [CrossRef]

10. Loncar, N.; Fraaije, M.W. Catalases as biocatalysts in technical applications: Current state and perspectives. Appl. Microbiol. Biotechnol. 2015, 99, 3351-3357. [CrossRef]

11. Kaushal, J.; Mehandia, S.; Singh, G.; Raina, A.; Arya, S.K. Catalase enzyme: Application in bioremediation and food industry. Biocatal. Agric. Biotechnol. 2018, 16, 192-199. [CrossRef]

12. Raducan, A.; Cantemir, A.R.; Puiu, M.; Oancea, D. Kinetics of hydrogen peroxide decomposition by catalase: Hydroxylic solvent effects. Bioprocess Biosyst. Eng. 2012, 35, 1523-1530. [CrossRef] [PubMed]

13. Katzbauer, B.; Narodoslawsky, M.; Moser, A. Classification system for immobilization techniques. Bioprocess Eng. 1995, 12, 173-179. [CrossRef]

14. Grigoras, A.G. Catalase immobilization-A review. Biochem. Eng. J. 2017, 117, 1-20. [CrossRef]

15. Chapman, J.; Ismail, A.; Dinu, C. IndustriaApplications of Enzymes: Recent Advances, Techniques, and Outlooks. Catalysts 2018, 8, 238. [CrossRef]

16. Wang, Q.; Lian, X.; Fang, Y.; Zhou, H.C. Applications of immobilized biocatalyst in metal-organic frameworks. Catalysts 2018, 8, 166. [CrossRef]

17. Ronai, I. How the techniques of molecular biology are developed from natural systems. SocArXiv 2017. [CrossRef]

18. Sooch, B.S.; Kauldhar, B.S.; Puri, M. Isolation and polyphasic characterization of a novel hyper catalase producing thermophilic bacterium for the degradation of hydrogen peroxide. Bioproc. Biosyst. Eng. 2016, 39, 1759-1773. [CrossRef]

19. Sadana, A. Enzyme deactivation. Biotechnol. Adv. 1988, 6, 349-446. [CrossRef]

20. Lardinois, O.M.; Mestdagh, M.M.; Rouxhet, P.G. Reversible inhibition and irreversible inactivation of catalase in the presence of hydrogen peroxide. Biochim. Biophys. Acta 1996, 1295, 222-238. [CrossRef]

21. Ghadermarzi, M.; Moosavi-Movahedi, A. Determination of the kinetic parameters for the "suicide substrate" inactivation of bovine liver catalase by hydrogen peroxide. J. Enzym. Inhib. 1996, 10, 167-175. [CrossRef] [PubMed]

22. Kirkman, H.N.; Gaetani, G.F. Mammalian catalase: A venerable enzyme with new mysteries. Trends Biochem. Sci. 2007, 32, 44-50. [CrossRef] [PubMed] 
23. Rovira, C. Structure, protonation state and dynamics of catalase compound II. ChemPhysChem 2005, 6, 1-8. [CrossRef] [PubMed]

24. Ghadermarzi, M.; Moosavi-Movahedi, A.A. The effects of temperature and $\mathrm{pH}$ on the kinetics of reactions between catalase and its suicide substrate hydrogen peroxide. Ital. J. Biochem. 1997, 46, 197-205. [PubMed]

25. Feuers, R.J.; Pattillo, F.M.; Osborn, C.K.; Adams, K.L.; DeLuca, D.; Smith, W.G. Application of an integrated rate equation to the inactivation of catalase. Free Radic. Biol. Med. 1993, 15, 223-226. [CrossRef]

26. DeLuca, D.C.; Dennis, R.; Smith, W.G. Inactivation of an animal and a fungal catalase by hydrogen peroxide. Arch. Biochem. Biophys. 1995, 320, 129-134. [CrossRef]

27. Chance, B. Effect of $\mathrm{pH}$ upon the reaction kinetics of the enzyme-substrate compounds of catalase. J. Biol. Chem. 1952, 194, 471-481.

28. Góth, L. Heat and pH dependence of catalase. A comparative study. Acta Biol. Hung. 1987, 38, $279-285$.

29. Cantemir, A.R.; Raducan, A.; Puiu, M.; Oancea, D. Kinetics of thermal inactivation of catalase in the presence of additives. Process Biochem. 2013, 48, 471-477. [CrossRef]

30. Aebi, H. Catalase in vitro. Methods Enzymol. 1984, 105, 121-126.

31. Miłek, J. Estimation of the kinetic parameters for $\mathrm{H}_{2} \mathrm{O}_{2}$ enzymatic decomposition and for catalase deactivation. Braz. J. Chem. Eng. 2018, 35, 995-1004. [CrossRef]

32. Santos, A.M.P.; Oliveira, M.G.; Maugeri, F. Modelling thermal stability and activity of free and immobilized enzymes as a novel tool for enzyme reactor design. Bioresour. Technol. 2007, 98, 3142-3148. [CrossRef] [PubMed]

33. Castro, R.J.S.; Ohara, A.; Nishide, T.G.; Albernaz, J.R.M.; Soares, M.H.; Sato, H.H. A new approach for proteases production by Aspergillus niger based on the kinetic and thermodynamic parameters of the enzymes obtained. Biocatal. Agric. Biotechnol. 2015, 4, 199-207. [CrossRef]

34. Beers, R.F.; Sizer, I.W. A spectrophotometric method for measuring the breakdown of hydrogen peroxide by catalase. J. Biol. Chem. 1952, 195, 133-140. [PubMed]

(C) 2020 by the author. Licensee MDPI, Basel, Switzerland. This article is an open access article distributed under the terms and conditions of the Creative Commons Attribution (CC BY) license (http://creativecommons.org/licenses/by/4.0/). 